Working Papers No. 142/10

Rethinking the Origins of British India: State Formation and Military-Fiscal Undertakings in an Eighteenth Century World Region

Tirthankar Roy

(C) Tirthankar Roy 
Department of Economic History London School of Economics Houghton Street London, WC2A 2AE

Tel: $\quad$ +44 (0) 2079557860

Fax: $\quad$ +44 (0) 2079557730 
Rethinking the Origins of British India: State Formation and Military-Fiscal Undertakings in an Eighteenth Century World Region ${ }^{1}$

Tirthankar Roy

\begin{abstract}
The paper discusses the rise of the East India Company in the contested political world of eighteenth century India, with reference to the manner in which economic power was deployed to enhance military power. It is shown that there was only one model of successful 'militaryfiscalism' in this time, represented by the Company. The Company's strategies, however, cannot be understood as a transplantation of European practices into India. Local factors, such as opportunism and access to the natural resources of the eastern Gangetic were important. However, institutional choices mattered, and owed in part to the Europeans' outsider status.
\end{abstract}

\title{
Introduction
}

Comparisons between early modern Europe and Asia in political terms are of abiding interest to global historians. ${ }^{2}$ Two types of motivation drive such comparisons. One of these is to explain Europe's precocious economic growth. And another is to explain colonization and conquest of Asian regions by Europe. The former enquiry has sometimes followed up the contrast between Europe's competitive state systems and Asia's empires, and suggested, as Eric Jones does, that political competition led in Europe to sovereign dependence on capital and to 'continual borrowing and .. "stimulus diffusion"' whereas the 'despotism' of the east functioned as 'a revenue pump' in the best of times, deteriorating into a chaotic 'fluctuations without development' in the eighteenth century. ${ }^{3}$ The case

\footnotetext{
${ }^{1}$ Revised version of paper for Asian Historical Economics Conference, Centre for China in the World Economy, Tsinghua University, May 19-21, 2010, Beijing.

${ }^{2}$ P.H.H. Vries, 'Governing Growth: A Comparative Analysis of the Role of the State in the Rise of the West', Journal of World History, 13(1), 2002, pp. 67-138.

${ }^{3}$ The European Miracle, Cambridge: Cambridge University Press, pp. xxx, 45, 161, $171,206$.
} 
for a contrast between dependent and despotic kings is undermined by the post-1980 scholarship on Indian empires, which projects a negotiated rather than hierarchical relationship between sovereigns and communities in this region. That criticism still leaves us with the question, how do we think about conquest and colonization in comparative terms?

Again eighteenth century India presents a problem for global history. In Europe, the outcome of political competition was states that grew in size and capacity, as the kings tried to take control of the economic means of financing wars, eventually redefining the role of the state in relation to the society. The European states in the eighteenth century had been moving towards sovereign control of the fiscal and the military apparatus, away from dependence on mercenaries, creditors, and contractors. ${ }^{4}$ The phrase, military-fiscalism, coined by Martin Wolfe in the context of Renaissance France, is frequently used to suggest a coevolution of fiscal capacity and military capacity. ${ }^{5}$ The attendant growth of 'social power' through a process of conflict brought about the nation state and the state structures that defined European modernization. ${ }^{6}$ In India too the dominant trend in this time was increasing contest between regimes that had succeeded the Mughal Empire. The break-up of the empire, and the struggle for revenue among contenders, unleashed much potential for violence. Rulers, noblemen, commanders, and underneath them, dominant peasant clans more or less lived in a state of war,

\footnotetext{
${ }^{4}$ Charles Tilly, 'Cities and States in Europe, 1000-1800', Theory and Society, 18(5), 1989, pp. 563-584. Mobilization of resources for war as a catalyst in the making of the fiscal system is emphasized in Patrick K. O'Brien, 'The Political Economy of British Taxation, 1660-1815', Economic History Review, 41(1), 1988, pp. 1-32, and in the formation of nation states by Brian Downing, The Military Revolution and Political Change in Early Modern Europe, Princeton: Princeton University Press, 1991. For an analytical treatment of the contribution of war to state capacity, see Timothy Besley and Torsten Persson, 'The Origins of State Capacity: Property Rights, Taxation, and Politics, American Economic Review, 99(4), 2009 , pp. 1218-44.

${ }^{5}$ The Fiscal System of Renaissance France, New Haven: Yale University Press, 1972.

${ }^{6}$ Michael Mann, Sources of Social Power, vol. 1, Cambridge: Cambridge University Press, 1986.
} 
especially in western and northern India. All of them were desperately seeking money and the means to acquire more money to finance warfare. And yet, the outcome of that contest was not collective empowerment of the states after the pattern of Western Europe, but something quite the opposite, a collective disempowerment and collapse. In keeping up the military enterprise, almost all of these political actors ran into fiscal crisis and the states that they tried to erect even shrank in size.

There was one large exception to this picture, and that was the English East India Company. The contest ended with the hegemony of the Company. One way of approaching the subject, therefore, would be to try to explain the final outcome of the competition. How did a company of foreign merchants triumph over powerful and militaristic Indian kings? Did military-fiscal strategies contribute to the rise of the Company? Did the European origin of the Company have any role to play in their militaryfiscal enterprise? The paper is an attempt to answer these three questions.

Most answers to the first question now available can be grouped under two heads, and called the fall-of-the-Indians and the rise-of-thewest stories. The oldest view was articulated in nineteenth century imperialist history and carried over into Indian nationalistic narratives of colonization. The point of emphasis was the exceptional features of the Indian state. Autocratic regimes collapsed under the weight of their own contradictions. 'Organized power having broken the field was left open for adventurers. ${ }^{7} \mathrm{~A}$ variation of the theme can be found in the regional historiography of the Maratha domain, which attributes military debacles to 'the feudal system and its fatal results', and to quarrels amongst chieftains. ${ }^{8}$ The second position attributes the outcome of the contest to

\footnotetext{
${ }^{7}$ Jawaharlal Nehru, Discovery of India, London: Meridien, 1946, p. 230.

${ }^{8}$ R.V.Nadkarni, The Rise and Fall of the Maratha Domain, Bombay: Popular

Prakashan, 1966, the cited text is the title of a section, pp. 352-363; The works of G.S.
} 
the Europeans' mercantilist ambitions, imperialist drive, and superior military organization and technology. ${ }^{9}$ 'Britain', it is suggested, 'was committed to securing its Indian interests at all costs'. ${ }^{10}$ The Europeans had an acknowledged lead in naval warfare. The decisive battles in the eighteenth century, however, were fought on land. In land warfare, the Europeans brought into India, if not a decisive advantage, some useful knowledge relating to infantry formation, command structure, professionalized officer corps, flintlock guns, cannons of cast iron, and mobile artillery. ${ }^{11}$ The Company's superior financial capacity enabled it to field a larger army than its Indian rivals' ${ }^{12}$ Others contend that the entire 'conquest of India' built upon opportunism, 'perfidious deals' that the Europeans struck with enemy factions and the wealthy merchants and bankers. ${ }^{13}$

Not all accounts of politics fit these overarching models. Uneasily co-existing with the failure of the Indians and the ingenuity of the Europeans is a third factor, luck, insofar as the Europeans had entrenched themselves in one of the resource-rich regions of India, the eastern Gangetic. ${ }^{14}$ Further, influential readings on northern India invite us to look at the changing structures of collaboration that the regional states depended on. In one view, agrarian and commercial expansion in

Sardesai, V.S. Khare, and others discussed leadership issues, see A.R. Kulkarni, The Marathas, New Delhi: Books and Books, 1996, pp. 177-180.

${ }^{9}$ On mercantilism, Vries, 'Governing Growth'.

${ }^{10}$ Barbara and Thomas Metcalf, A Concise History of India, Cambridge: Cambridge University Press, 2001, p. 53.

${ }^{11}$ Geoffrey Parker, The Military Revolution: Military Innovation and the Rise of the West 1500-1800, Cambridge: Cambridge University Press, 1988, p. 136. Also G.J. Bryant, 'Asymmetric Warfare: The British Experience in Eighteenth-Century India', The Journal of Military History, 68(2), 2004, pp. 431-469.

${ }_{12}$ Metcalf and Metcalf, Concise History of India, p. 54.

${ }^{13}$ Deepak Lal, 'Asia and Western Dominance', Journal of the Asia Pacific Economy, 8(3), 2003, pp. 283-99.

14 'The English already held the most prosperous regions', writes Stewart Gordon, The Marathas 1600-1818, Cambridge: Cambridge University Press, 1993, p. 193. C.A. Bayly notes 'the lack of resources' of the lands that formed the heart of the Maratha domain, Indian Society and the Making of the British Empire, Cambridge: Cambridge University Press, 1990, p. 102. 
the seventeenth century had empowered the landed gentry, merchants, bankers, scribes, and other literate officers of the state. ${ }^{15}$ The position of these groups, whose members did not come from traditional families holding military and fiscal tenures, was further strengthened in the eighteenth century via revenue farming on which the post-Mughal states depended. First advanced for the western Gangetic plains, capitalist consolidation was later extended to states in peninsular India. ${ }^{16}$ The accumulation of wealth among Indian merchants and bankers was potentially destabilizing for the regional states, because the interests of the former were more consistent with those of the Company than of the Indian nobility. The European trade settlements attracted merchants and bankers from all over India. The first major military encounter between the Company and a provincial army, the battle of Plassey (1757), has been described as 'a transaction, not a battle', by an Indian historian. ${ }^{17}$ Recent eighteenth century historiography makes a case that the Company State resembled the Indian states in aims and strategies too closely to permit seeing a rupture in the transition to British Empire. The thesis of merchant

${ }^{15}$ C.A. Bayly, Rulers, Townsmen and Bazaars: North Indian Society in the Age of British Expansion 1770-1870, Cambridge: Cambridge University Press, 1983; Muzaffar Alam, Crisis of Empire in Mughal North India: Awadh and the Punjab 1707-48, Delhi: Oxford University Press, 1986.

${ }^{16}$ The introductions of P.J. Marshall, ed., Eighteenth Century in Indian History: Evolution or Revolution?, Delhi: Oxford University Press, 2003, pp. 1-30; Seema Alavi, ed., Eighteenth Century in India, Delhi: Oxford University Press, 2002, pp. 1-56; Also useful are Om Prakash, 'The Great Divergence: Evidence from Eighteenth Century India', Paper presented at the Seventh GEHN Conference at Istanbul, 2005; Rajat Datta, 'Commercialisation, Tribute, and the Transition from Late Mughal to Early Colonial in India', Medieval History Journal, 6(2), 2003, pp. 259-291; Binay Chaudhuri, Peasant History of Late Pre-colonial and Colonial India, Delhi: Pearson Longman, 2008, pp. 49-107.

${ }^{17}$ K.M. Panikkar, cited in Lal, 'Asia and Western Dominance'. See also on merchant collaboration, David Washbrook, 'India in the Early Modern World Economy: Modes of Production, Reproduction and Exchange', Journal of Global History, 2(1), 2007, pp. 87-111. For another statement, see David Arnold and Burton Stein, A History of India, Second Edition, Malden and Oxford: Wiley-Blackwell, pp. 197-8. 
collaboration illustrates the idea of a gradual evolution, even continuity between the pre-colonial and the colonial. ${ }^{18}$

There is truth in all of these accounts. And yet, individually, each one of these positions raises problems. Concepts of the state underlying the decline story stand much revised. The suggestion that India's 'feudal' order had something to do with battlefield outcomes implies that the crucial difference was an institutional one, but how the Europeans dealt with the Indian institutional order is left unsaid. The emphasis on quarrelsome leadership in Maratha history makes it difficult to compare the Maratha situation with those of the other Indian states. ${ }^{19}$ The rise-ofthe-west story is problematical too. Mercantilism did not easily translate into imperial expansionism in India. ${ }^{20}$ The relationship between the two motivations was complex and unpredictable. To suggest that making 'perfidious deals' with factions of the enemy was a forte of the Europeans whereas their Indian adversaries were lost in innocence, is wrong on grounds of fact, as well as theory, since unprincipled intrigue as a weapon of war is sanctioned in all ancient Indian manuals on statecraft.

The proposition that the Europeans possessed superior military knowledge lives uneasily with the fact that there was convergence in knowledge even as there was divergence in battlefield outcomes. ${ }^{21}$ The practice of hiring European mercenaries by the Indian regimes was so extensive that a distinction cannot be maintained between European and

\footnotetext{
18 'Introduction', in Marshall, ed., Eighteenth Century; and 'Introduction', in Alavi, ed., Eighteenth Century.

${ }^{19}$ Mysore under Tipu Sultan, or Hyderabad under the Nizam-ul-mulk did not suffer from divided leadership.

${ }^{20}$ For at least thirty years after the Company registered a decisive military success in Bengal (Plassey, 1757), '[w]ar, conquest and the extension of territory were condemned as contrary to the interests of a trading company' in the British political mainstream. P.J. Marshall, Problems of Empire: Britain and India 1757-1813, London: George Allen and Unwin, 1968, p. 63.

${ }^{21}$ On convergence, Kaushik Roy, 'Military Synthesis in South Asia: Armies, Warfare, and Indian Society, c. 1740-1849', The Journal of Military History, 69(3), 2005, pp. 651690, and John Pemble, 'Resources and Techniques in the Second Maratha War', The Historical Journal, 19(2), 1976, pp. 375-404.
} 
Indian spheres of knowledge in the second half of the century. ${ }^{22}$ The distinction is blurred even more when we consider that the Company's army relied mainly on Indian soldiers with a thin layer of European command above them. The proposition that the Europeans fielded larger armies in the most consequential battles is possibly wrong. What we can be sure of is that the proportion of regular soldiers was significantly higher in the Company army, and that the army expanded in the nineteenth century. If the composition of the army played any role, we need to ask why the Indian regimes were constrained from adopting the best strategy. To sum up the critique with a broader point, using the ethnicity of the ruler to make sense of state formation is likely to fail, for such an approach blurs similarities and convergent tendencies between the Indians and the Europeans, just as it blurs important points of distinctness amongst the Indian regimes. I return to this issue in the next section.

Geography alone does not explain conquest, for the Europeans shared the fertile Gangetic floodplains with other regimes. If natural resources were all that mattered to military success, why did pre-colonial Bengal, Rohilkhand, or Awadh, all fortunately situated, cave in to the Afghans, Marathas, or the Europeans? Commercialization as a potentially destabilizing force needs to be treated with caution. The obvious objection to the view that capitalist consolidation weakened the Indian regimes is that these regimes were just as heavily dependent on the private sector as was the Company. On the other side, the equation between Indian commercial interests and the Company was not necessarily a stable one, and often characterized by elemental distrust.

\footnotetext{
${ }^{22}$ The most famous examples were Tipu Sultan of Mysore, Mahadaji Sindhia (Shinde), ruler of the Bundelkhand arm of the Maratha domain, and Ranjit Singh of Punjab. On Mahadaji's enterprise, see Letters, Political, Military and Commercial on the Present State and Government on the Province of Oudh and its Dependencies, c. 1793, p. 25. See also J.P. Thomson, 'An Autobiographical Memoir of Louis Bourquien', Journal of the Punjab Historical Society, 9(1), 1923, pp. 36-71. All of the rulers, and especially Mysore, tried to control trade in military equipment and manufactured cast-iron cannons under European supervision.
} 
Further, banker support was hardly an independent variable in explaining the political or fiscal stability of regimes; the causation should run the other way. The new thinking on eighteenth century India, which too readily assumes that most regions experienced an energetic capitalist flourish, even economic growth, needs to convince the analytically oriented economic historian that commercial and economic growth were possible at all in the backdrop of small, vulnerable, and shrinking states left with too little money to spend on infrastructure and public goods. Finally, the precise connection between a wealthy private sector and battlefield outcomes remains to be shown.

In some writings on eighteenth century state formation, it is recognized that battlefield strategies entailed fiscal innovations on both sides. In that spirit, Burton Stein read late-eighteenth century Mysore as an embryonic military-fiscal state. ${ }^{23}$ C.A. Bayly uses the idea to clarify the nature of western imperialist expansion in India. ${ }^{24}$ As these two examples might suggest, applying the concept of a single strategy to winners and losers alike deprives the concept of analytical value. Indeed, the emphasis in recent thinking on the element of continuity between the precolonial and the colonial states results in 'military fiscalism' being applied somewhat indiscriminately to diverse contexts. ${ }^{25}$

The arguments of the paper can now be briefly stated. I advance in this paper four connected theses on the colonization of India.

First, there was only one model of successful military fiscalism in eighteenth century India, and it was represented by the East India Company. Several of the prominent Indian states, as they fought more

\footnotetext{
23 'State Formation and Economy Reconsidered. Part One', Modern Asian Studies, 19(3), 1985, pp. 387-413.

24 'The British Military-Fiscal State and Indigenous Resistance. India 1750-1820', in Lawrence Stone, ed., An Imperial State at War: Britain from 1689 to 1815, London and New York: Routledge, 1994, pp. 322-354. See also John Brewer, The Sinews of Power: War, Money, and the English State, 1688-1783, Cambridge Mass.: Harvard University Press, 1990.

${ }^{25}$ See for example, Alavi, 'Introduction'.
} 
battles, shrank in size. The Company alone managed to raise its revenue while continuing the war effort. The Company state, in this respect, did represent a revolutionary force in Indian politics, and a fundamental rupture in the concept of statecraft. The proposition, thus, entails a revision in the historiography of state formation in eighteenth century South Asia.

Second, the Company's success in this respect cannot be understood as a transplantation of European practices into India. In the middle of the eighteenth century, the political game being played by the Company was quite similar to that being played by its principal rivals. Wealth and power did not always join together in early eighteenth century India. Much negotiation and violence were a response to attempts by the militarily strong regimes hailing from resource-poor regions, regimes that I call commander-ruled, to stake a claim upon the revenue of the virtually stateless former imperial provinces, as well as that of the richer states that were controlled by the remnants of the imperial administration. If there was competition in this scenario, it was competition in a market for protection among the militarily weaker states, involving negotiation on the tribute to be paid in exchange for alliance against worse predators. In the 1750s, the main contenders in northern India were the Afghans and the Marathas. In the second half of the century, the Marathas lost an important encounter, the Afghan factor receded, and the Company joined the contest as a worthy player. The emergence of new militarily strong regimes in the backdrop of a market for protection gave rise to two parallel modes of governance, 'statism' or attempts to control military and land revenue administration jointly, and 'militarism' or the superimposition of a centralized military outpost over a decentralized land revenue 
administration. ${ }^{26}$ Until the very end of the century, major Indian powers tried to combine strategies. The Maratha domain combined a greater degree of statism in Maharashtra with militarism in Hindustan, the Company combined statism in Bengal with militarism in Awadh, and Mysore, while targeting Travancore for practice of militarism, tried to erect a statist setup in the core domain.

Third, geography mattered. Seeds of a divergence can be found in the emerging pattern of control over regional resources. With its strategic base in the seas, the Company had secured itself in the littoral and deltaic zones. The productivity of land varied enormously between the floodplains of the Ganges and the dry interior, possibly by as much as a factor of four. Regions with higher land yield generated more revenue per square mile. The Company was fortunate in taking control of Bengal and Awadh, the two richest regions of India. Access to larger funding, and a favourable debt-income ratio, enabled it to expand the regular army, whereas there was a trend towards increasing dependence on mercenaries among its rivals.

Fourth, geography alone cannot explain the divergence; institutional choices mattered too. The Indian states, which could sustain the military enterprise only by offering fiscal concessions and tenures to commanders, saw their power wither away in the presence of sustained conflict. The Company on the other hand recast the relationship between the state and the intermediate order of agents engaged in taxation, by making use of an unprecedented instrument, offer of marketable property rights to the landlords in exchange for compliance to the new militaryfiscal order. How do we understand this institutional difference? I submit that global (ideological) and local (geographical) factors need equal consideration, and in mutual relation. The Company did not originate in

${ }^{26}$ These were not exclusive alternatives, in fact, statism would be impossible to attain without the capacity to perform militarism. Therefore, a militarily weak regime would have no choice at all. 
an indigenous community, and therefore had no military heritage to defend, nor an interest in maintaining sectarian property rights. The fact that it came from a world which had been adapting to constant wars by means of centralization of finances and conscriptions, made it readier than any Indian state of the time to try to consolidate sovereignty. The Indian states had a path dependence to live with, namely, shared sovereignty with communities and individuals who supplied useful services, principally military services. Conflicts, therefore, led them to give away more powers. The higher revenue per area reduced the costs of territorial administration and policing potential rebels in the Company territories. In short, the coasts and flood-plains made military-fiscalism more promising than in the rocky landscape where Tipu Sultan designed his statist reforms. In the arid Deccan plateau and forested central India, devoid of good roads, much commerce, and large towns, it was considerably harder for the kings to shed their dependence on local bosses possessing adequate knowledge of the land and the means to coerce peasant headmen.

The rest of the paper has three main sections, dealing with, respectively, a restatement of political history that frames the whole project, discussion of fiscal policy, and institutional policy, respectively. The last section concludes. 


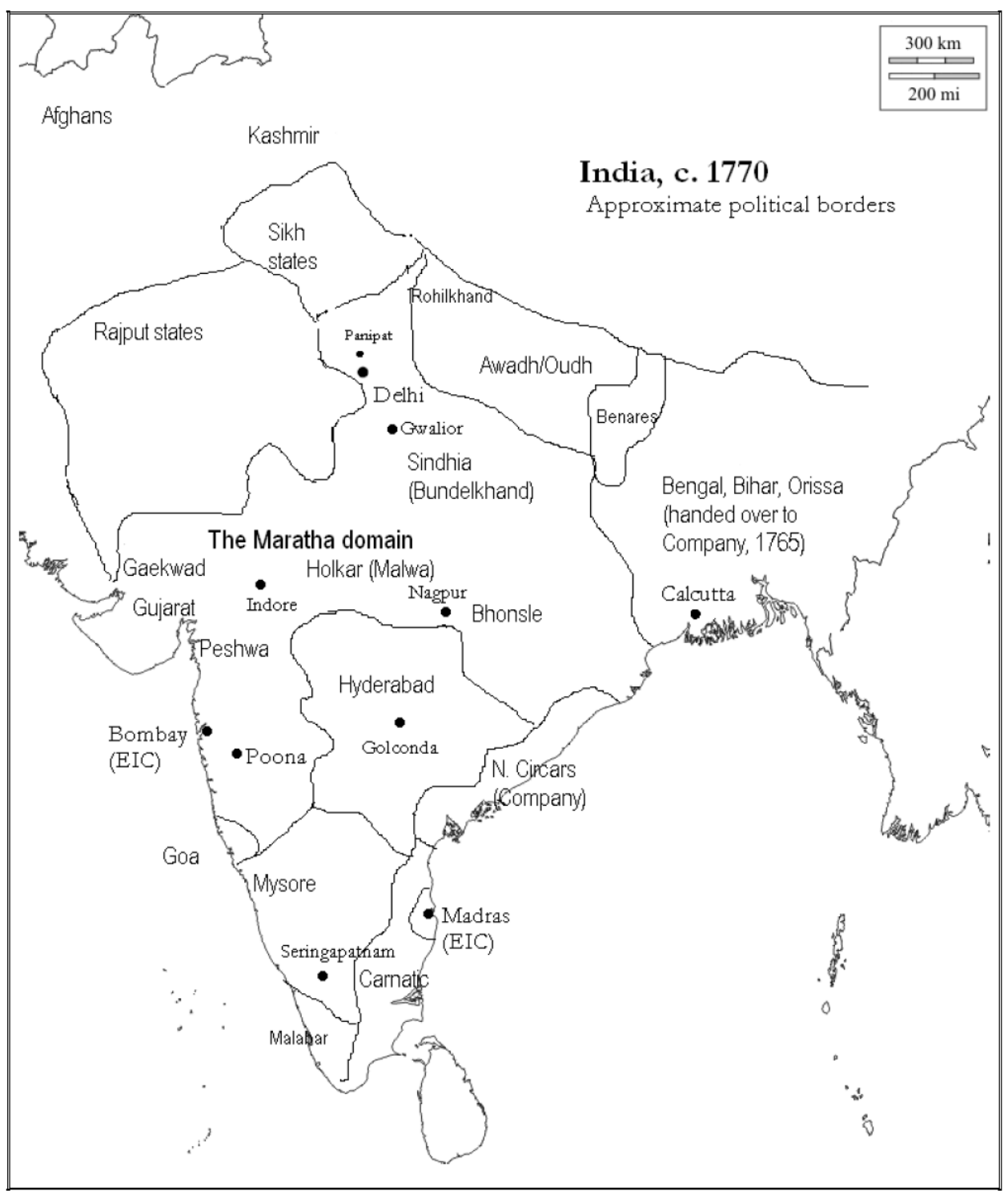




\section{The Political Process}

It is useful to begin with the Mughal polity. Generally speaking, medieval rulers maintained territorial control by assigning revenue grants to military commanders, who in turn relied on the local gentry for collection of taxes from the peasants, for organizing extension or improvement in cultivation, for maintenance of law and order, and for military supplies. In Mughal India, the command of cavalry was an honour bestowed by the Emperor for distinguished military service upon deserving candidates, and a mark of hereditary or acquired nobility. But such command was also a potential threat to royal power. The revenue assignment that the military elite were rewarded with (jagir), therefore, was in principle not a hereditary or proprietary one, but transferable. In its pure form, the jagir signified a notional share over a region's tax resources; the holder of that office had little actual contact with the region concerned. Underneath these groups were the gentry or the landlords (zamindar), who lived in proximity of the peasant, collected and paid the land tax, and sometimes rose from the ranks of the peasants. Technically a tax-collector rather than proprietor, the landlord often enjoyed an effectively hereditary right. Like the jagirdars, they almost always owned arms, but their position was contingent on control of cultivation rather than control of soldiers.

The situation in southern, western, and eastern India maintained broad similarity with the northern one on the point of a tiered structure of rights based on tax collection. One difference was that in peninsular India, local military authority was often vested in a tributary king. The tributary king lived on land tax, lived in a fort, was in command of an army at the service of the regional state, but did not necessarily belong in the nobility. In the Deccan sultanates and Gujarat, tributary kings were common figures in the eighteenth century. 
Within a few years after the death of Aurangzeb (1707), the Mughal Empire began to disintegrate. The break-up of the Mughal Empire has been attributed to various factors, such as fiscal crisis generated by constant wars, Aurangzeb's religious intolerance, the intrigue of nobles and ministers, and lack of financial support. ${ }^{27}$ Not all of these factors are relevant to this paper. One factor, however, is relevant. Between 1690 and 1720 , almost everywhere the equation between the four major constituents of early modern states - the king, the commander, the landlord, and the peasant - was beginning to change. In this backdrop, the formation of the successor states followed broadly two pathways, towards what I call rule by noblemen and rule by commanders.

As Delhi witnessed the phenomenon that James Tod called fleeting phantoms of royalty, major provincial rulers loyal to Delhi such as the Nizam in Hyderabad, Murshid Quli Khan in Bengal, and Safdarjang in Awadh consolidated their finances and armies, and in their capacity as 'advisors' to the Emperor grew more powerful than the Emperor himself. While formally owing allegiance, they profited from the troubles the Emperor faced coping with rebellions and invasions. Despite the relatively peaceful transition, these regimes faced insurrection by landlords, and at times that of the military commanders. But they escaped usurpation of state power. There were several stabilizing forces at work. A substantial number of military tenures remained loyal to the king, who commanded symbolic authority as a representative of the Emperor, though the state had lost the authority to enforce transferability of these rights. Further, banking was relatively advanced in these regions, and the rulers commanded credit.

Away from the spheres of influence of the Mughal governors, or Nawabs, state formation followed a different trajectory. The west ruled by

\footnotetext{
${ }^{27}$ J.F. Richards, 'Mughal State Finance and the Premodern World Economy', Comparative Studies in Society and History, 23(2), 1981, pp. 285-308.
} 
Rajput states, the western Deccan ruled by the weak state of Bijapur, and in the south the states left behind by Aurangzeb's unfinished conquests, had never been administratively or politically integrated into the Empire. Their own spheres of authority, however, were contested in the early eighteenth century. From the turmoil, four major territorial and military powers emerged in peninsular India - the Marathas based in Poona, Mysore under Haidar Ali, The English East India Company, and the French East India Company, both based in the Coromandel coast. If the merchant companies are excepted, the pathway to state formation in these examples involved assertion of independence by the two intermediate orders - commanders and landlords - at the expense of the nobility. In the Deccan, Mysore, Punjab, and the lands populated by Rajput, Jat and Rohilla Afghans, these agents claimed either kingship or vassal status of the Emperor.

The most consequential example of the second pathway was the Maratha domain in the second half of the seventeenth century. The individuals and families that later formed Maratha states, had been engaged by the Deccan sultans as military commanders and members of the irregular army. The position of strength in which these people found themselves was the culmination of service under the Deccan sultanates, during which hill forts came to be garrisoned by the Marathas. ${ }^{28}$ Rallying under Shivaji, they resisted the sultans, and posed an obstacle to Mughal ambitions in the Deccan. By the end of the century, they exercised effective control over parts of present-day Maharashtra. In the first half of the eighteenth century, the army enlarged in size, and conquests were made of Gujarat, Malwa, Bundelkhand, and Berar, which became parts of a network that British writers alternatively called 'empire', 'republic', or 'confederacy', and I will call by a fourth option 'domain'. In the 1750s, the

${ }^{28}$ James Grant Duff, A History of the Mahrattas, vol. 1 of 3, Bombay: Exchange Press, 1863. 
north-western tributaries of the Mughal Empire became a target of the Afghan rulers. The Marathas had also been making moves towards the northwest. In the third battle of Panipat (1761), a combination of Afghan, Awadh and Rohilla forces defeated the Maratha army. ${ }^{29}$ Although losing the capacity to carry out further conquests, Maratha forces of Bundelkhand and Malwa regrouped and raided both the western Gangetic and eastern Rajasthan, until the second and the third AngloMaratha wars (1803-4 and 1817-8) led to annexation of much of their lands by the Company.

Commander-ruled states in northern India arose from Rajput rebellions in eastern Rajasthan, and in the western and eastern Gangetic. In Rohilkhand or Katehr, an agriculturally prosperous segment of the western Gangetic plains, former commanders under the Mughals established an independent rule between 1710 and 1750. Rohilla power after 1765 was weakened by invasion of Maratha and the Company army. A different example of commander rule occurred in Mysore, where a military general, Haidar Ali, became the de facto ruler in 1761. For the next 38 years, Haidar Ali and his son Tipu Sultan tried to create an effective military administration in the region. A final example of the formation of a state out of military command was Punjab, where Ranjit Singh, who came to power in 1799 , succeeded, like Shivaji, in uniting the majority of the clans and their chiefs into a viable alliance. The resultant improvement in central finances enabled him to strengthen and modernize the army. Soon after his death in 1839 , inter-clan rivalry reappeared, and partly taking advantage of these conflicts, the Company annexed Punjab in 1849.

The core political process in the eighteenth century saw the two pathways of state formation become entangled. The commander-ruled

${ }^{29}$ On the Maratha-Afghan military contest, see Jos Gommans, 'Indian Warfare and Afghan Innovation during the Eighteenth Century', Studies in History, 11(3), 1995, pp. 261-280. 
states in the Deccan displayed a propensity towards territorial expansion not so much by outright conquest as sending military missions to demand protection money. Mysore eyed Malabar and Coromandel, and the Marathas Delhi, Awadh, Rohilkhand, Punjab, and briefly Bengal. The principal targets were the nobility-ruled states, located in the much wealthier tracts of land, who responded rarely by military means, and more often by means of alliances, tributes, and intrigues. Early in the second half of the century, two events presaged a change in this process. In 1761, the Peshwa's army lost at Panipat. And in 1765, the Company received the taxation rights of Bengal from the Mughal Emperor. The two events did not introduce any immediate or fundamental break, especially since the mutinous Afghan army had to leave Delhi. But it led the way to a larger role for the Company in the north Indian theatre, and increased the choice of 'protectors'. The Company now became a useful ally to some, and a potential threat to the survival of any ruler who did not negotiate. In a series of battles, the Company fought with all of the major powers, with the exception of the Nizam. It suffered reverses and losses in the 1770s, but from the 1790s, won the battles that made a difference to the future political map of India.

It is well-known in military history that the Company's success partly owed to an army that was more capital-intensive than those of its rivals and dependencies. Where did the capital come from?

\section{Patterns of Military-Fiscalism}

I consider a scenario where the proportion of state expenditure on army is relatively high, and the state expands the scale of revenues, to be the mark of sustainable expansion of fiscal capacity driven by military goals. It is not easy to measure the index. The Company maintained regular accounts, if in an archaic style, to show to the Parliament how 
much its Indian adventures cost. Public finance accounts of the Indian states are hard to find and harder to read. The scarcity of aggregate data is compounded by the fact that by far the larger part of the rich historical scholarship on eighteenth century Maratha and Mysore deals with diplomatic and military history. On the other hand, this difference in the quality of data illustrates the very hypothesis I examine here, that the attempt at fiscal consolidation proceeded in an uneven fashion. The difficulty of estimating the income of any state in this time was the presence of multiple claimants (kings and jagirdars) and multiple centres (core zone and tributary zones).

Despite these difficulties, two facts cannot be disputed. The proportion of the military in total expenditure was universally high in the second half of the century (Table 1). And the revenue flows to all Indian states together fell in the eighteenth century (Table 2 ). There was only one exception to the second proposition, and that was the Company. There was no dramatic increase in revenue immediately after the takeover of fiscal administration in Bengal. The 1770 Bengal famine even destroyed some of the initial gains. However, there was acceleration thereafter as the Company consolidated its land administration. On the Indian side, the falls partly reflected territorial losses but not wholly so. The crisis owed to a weakening hold of the state upon its revenue assignees and officers. The revenue per unit of area or population did not rise to offset territorial losses. The Peshwa's revenues declined from $£ 4$ million in 1765 to 2.1 million in 1813 and 1.6 before British takeover. ${ }^{30}$ In 1770, Haidar Ali's dominions yielded revenue of about 0.8 million, which

\footnotetext{
${ }^{30}$ Calculations by V.G. Khobrekar, cited by V.D. Divekar, 'Survey of Material in Marathi on the Economic and Social History of India - 2', Indian Economic and Social History Review, 15(2), pp. 221-240.
} 
Tipu's conquests increased to 2.8 in $1792 .{ }^{31}$ The territory carved up by the alliance between the Company, Nizam, and the Marathas after the fall of Tipu produced revenue of $£ 1.4$ million. The territory of Mysore returned to the Wodeyar king produced estimated revenue of 0.4 million (Table 3). Other instances of decline include Rohilkhand, where the end of Rohilla power led to a significant fall in revenues flowing into the Awadh state. ${ }^{32}$

The Company could not finance wars from its income. The proportion of interest-bearing-debt-to-revenue ratio rose from 120 per cent in 1793 to over 300 in 1809 , declining to 200 per cent in $1833 .{ }^{33} 90$ per cent of the war finance was raised in India. Although the cost of credit was about half (5 per cent) in England of that in India, the share of the English money market did not rise until after the territorial wars were over. In other words, all major rival states in the late-eighteenth century competed for money in the same money market. Credit was also critical to the other states. Possibly a quarter of the aggregate Maratha revenues in 1763-5 came from loans. Rs. 10 million were taken from the bankers, according to one estimate for the $1760 \mathrm{~s} .{ }^{34}$ Where then was a difference between British territories and their Indian rivals? In Peshwa's territory, debt service in the 1760s took away about a third of the net income of the state. There is reason to believe that Panipat left a permanent effect upon sovereign debt. In British India, in the decade of the third Anglo-Maratha wars, debt service as a percentage of revenue fell from nearer 20 per cent to 12 per cent. ${ }^{35}$ In the second and the third Anglo-Maratha wars, the

\footnotetext{
${ }^{31}$ Sanjay Subrahmanyam, 'Warfare and State Finance in Wodeyar Mysore 1724-25: A Missionary Perspective', Indian Economic and Social History Review, 26(2), 1989, pp. 203-233.

${ }^{32}$ E.I. Brodkin, 'British India and the Abuses of Power: Rohilkhand under Early Company Rule', Indian Economic and Social History Review, 10(2), 1973, pp. 129-56. ${ }^{33}$ B.P.P. 1810 (363) Select Committee, pp. 94-96; Charles Macfarlane, A History of British India, London: George Routledge, 1853, p. 522.

${ }^{34}$ V.D. Divekar, 'The Emergence of an Indigenous Business Class in Maharashtra in the Eighteenth Century', Modern Asian Studies, 16(3), 1982, pp. 427-443.

${ }^{35}$ W.H. Sykes, 'The Past, Present, and Prospective Financial Conditions of British India', Journal of the Statistical Society of London, 22(4), 1859, pp. 455-480.
} 
Maratha states raised money by mortgaging the right to give land grants. ${ }^{36}$ These figures suggest that sustainable capacity to borrow varied according to taxable capacity.

${ }^{36}$ The Company's dependencies by then were under a burden of tribute that left them financially incapable of raising an army, and bound by treaties that restrained their military options. For Awadh, see Copy Proceedings and Correspondence relative to the State and Condition of the Country of Oude and its Dependencies, and of the Reigning Family thereof; including the Charges made by Mr. Hastings against Mr. Bristow, \&c. \&c. \&c., p. 30 
Table 1. Military Charges in Total Revenue

\begin{tabular}{|c|c|}
\hline & $\begin{array}{l}\text { Percentage of direct military } \\
\text { expenditure in revenue }\end{array}$ \\
\hline Bengal, Bombay, Madras, 1796-1797, average ${ }^{a}$ & 81 \\
\hline Combined British territories, $1819-20^{b}$ & 65 \\
\hline Awadh, 1784-1792, average ${ }^{c}$ & 74 \\
\hline Peshwa's territory, c. $1780^{\mathrm{d}}$ & 80 \\
\hline Hyderabad, c. $1800^{\mathrm{e}}$ & $>40$ \\
\hline Mysore, $1799^{f}$ & $40-80$ \\
\hline
\end{tabular}

\section{Notes:}

a. British Parliamentary Papers, 'An Account of the Annual Revenues of the East India Company'.

b. W.H. Sykes, 'The Past, Present, and Prospective Financial Conditions of British India', Journal of the Statistical Society of London, 22(4), 1859, pp. 455-480.

c. Tribute paid to the Company for the defence of Awadh (average over 1786-1792) is taken as a proportion of revenues (average over 1784-89). Letters, Political, Military and Commercial on the Present State and Government on the Province of Oudh and its Dependencies, c. 1793.

d. The revenue corresponds to actual inflow of cash into the treasury, and expenditure consists of payment to troops 'who receive their allowances in ready money', and maintenance of the 700-odd forts. 'Of the Productions and Peculiarities of the Marratta Country', Asiatic Miscellany, 1792, pp. 153-162. The revenue estimate is based on impression. But the amount, Rs. 50 million, is not improbable, since official accounts show that in 1789, total inflow of tribute to the Peshwa state from subahs in Hindustan and Gujarat amounted to Rs. 21 million, see V.S. Kadam, Maratha Confederacy, Delhi: Munshiram Manoharlal, 1993, pp. 74-5.

e. Refers to c. 1830, and includes tribute to the Company and expenditure on domestic troops. I assume that the 1800 expenditure on the military establishment exceeded this percentage because of the ongoing hostilities with Mysore, p. 62.

f. Infantry wages are assumed to range between Rs. 50 and 100 and cavalry Rs. 200 and 400 per annum. The foot-soldiers of Maratha households (paga) in 1800 earned Rs. 8 per month. The cavalry-infantry wage-ratio was usually 4:1 in the case of Awadh and the Company. For revenue, see Table 3 . The assumptions are conservative. In a market characterized by high risk and high demand, wage structure was unstable. The salaries of European mercenaries as well as Indian commanders and musketeers immediately before a battle bore little relation with the regular pay and allowances of foot soldiers. In the 1764 Buxar campaign the Awadh Nawab Shujauddaula paid Rs. 300-1000 per month to his European commanders. Bartholomew Burges, A Series of Indostan Letters, New York, 1790, p. xxii. 
Table 2. Estimated State Income, 1667-1853 (million $£$ )

\begin{tabular}{lcccccc}
\hline & c. 1667 & $1707-09$ & 1764 & 1800 & 1818 & 1853 \\
\hline $\begin{array}{l}\text { Revenues of all states in } \\
\text { India }\end{array}$ & $26^{\mathrm{a}}$ & $38^{\mathrm{b}}$ & - & $22-29$ & - & $34^{\mathrm{c}}$ \\
$\begin{array}{l}\text { British India } \\
\text { Indian states }\end{array}$ & - & - & 3 & 8 & 13 & 21 \\
\hline $\begin{array}{l}\text { Major Indian states } \\
\text { (before annexation) }\end{array}$ & 26 & 38 & - & $14-21^{\mathrm{e}}$ & - & 13 \\
\hline $\begin{array}{l}\text { Awadh } \\
\text { Hyderabad }\end{array}$ & 0.8 & $-0.9^{\mathrm{a}}$ & - & 0.8 & - & 1.4 \\
$\begin{array}{l}\text { Bengal, Bihar, Orissa } \\
\text { Peshwa }^{\mathrm{d}}\end{array}$ & - & $2.8^{\mathrm{a}}$ & - & - & - & 1.5 \\
& 3.6 & $2.8^{\mathrm{a}}$ & 2.6 & - & - & - \\
& - & - & 4.0 & 4.0 & 1.6 & -
\end{tabular}

a. Aggregate of all Mughal provinces. Irfan Habib, The Agrarian System of Mughal India 1556-1707, Delhi: Oxford University Press, 1999, pp. 455-9.

b. Aggregate of all Mughal provinces. William Bolts, Considerations on India Affairs, London: J. Almon, 1772, p. 17.

c. See Table 5.

d. British Parliamentary Papers (B.P.P.) 1810 (363), Select Committee on Affairs of East India Company Second Report, Appendix, pp. 16-26; Sykes, 'Past, Present, and Prospective Financial Conditions'.

e. Estimates exist for some of the Maratha territories, and Awadh (Table 3). A segment of these two regions accounted for half the revenues of the princely states in 1853 . On this basis, I consider that the princely states we do not have any data for could produce over half but less than two-thirds of the income of the Indian states. Two estimates of aggregate Maratha revenues in this time produce 12 million (1792) and 16 million pounds (1800). If we accept these numbers, the revenue of the Indian states should increase to 28-32 million, still smaller than the number for 1707. However, these were conjectural numbers, and hugely exaggerated the taxable capacity of the Maratha domains in Hindustan. 
Table 3. Area and Estimated Revenue, 1780-1817

\begin{tabular}{|c|c|c|c|}
\hline & $\begin{array}{l}\text { Approximate } \\
\text { territorial extent } \\
\text { in square miles }\end{array}$ & $\begin{array}{l}\text { Estimated } \\
\text { revenue, } \\
\text { million } £\end{array}$ & $\begin{array}{l}\text { Revenue } \\
\text { per square } \\
\text { mile }\end{array}$ \\
\hline Mysore, 1799 (after annexation) $^{\mathrm{a}}$ & 29,000 & 0.41 & 14.2 \\
\hline Peshwa, $1780^{\mathrm{b}}$ & 120,000 & $4.00-5.00$ & $33.0-41.7$ \\
\hline Peshwa, $1800^{c}$ & 120,000 & 4.00 & 33.0 \\
\hline Peshwa (after annexation), $1818^{\mathrm{d}}$ & 50,000 & 0.50 & 10.0 \\
\hline $\begin{array}{l}\text { Bhonsle and Sindhia (after } \\
\text { annexation), } 1818^{\mathrm{e}}\end{array}$ & 70,000 & 0.25 & 3.6 \\
\hline Bengal, $1795^{f}$ & 110,000 & 5.80 & 52.0 \\
\hline Awadh, $1781^{g}$ & 29,000 & 0.70 & 24.1 \\
\hline Awadh, $1801^{g}$ & 29,000 & 0.79 & 26.5 \\
\hline Travancore, $1807^{\mathrm{h}}$ & 8,100 & 0.25 & 30.9 \\
\hline
\end{tabular}

\section{Sources:}

a. James Mill, A History of British India 1805-1835, vol. 1, London: James Madden, 1858, pp. 4. The figures, reported in Kanthirai pagoda, were converted at the rate of 3 current rupees to a pagoda.

b. V.D. Divekar, 'Survey of Material in Marathi on the Economic and Social History of India - 2', Indian Economic and Social History Review, 15(2), pp. 221-240, and 'Productions and Peculiarities', Asiatic Miscellany. For want of a better benchmark, I have retained the size of the Bombay Presidency as the proxy for tributary area. A midnineteenth century source places the size of the territory at 100,000 square miles. William Henry Tone, 'lllustrations of Some Institutions of the Mahratta People', Calcutta Review, 4(7), July-December 1845, pp. 178-240. The revenue is the amount actually deposited in the treasury.

c. John Taylor, Letters on India, London: Carpenter, 1800, p. 194.

d. H.H. Wilson, A History of British India 1805-1835, vol.2, London: James Madden, 1858, pp. 279-80. The Peshwa's territory acquired by the Company after the third AngloMaratha war amounted to an estimated 50,000 square miles and extended from Khandesh to Canara, and Konkan to western Deccan. The tributary domain was considerably smaller than the area from which the Peshwa had received income in 1780.

e. Wilson, History, vol. 2, p. 283. Both the area and the revenue seem to have been underestimated.

f. British Parliamentary Papers, 'An Account of the Annual Revenues of the East India Company'.

g. H.M. Lawrence, Essays, Military and Political Written in India, London: W.H. Allen, 1859, p. 101. The figures, when reported in Fyzabad rupees, were converted using the exchange of 2.9 Fyzabad rupees to a current rupee.

h. Mill, History, vol. 1, p. 5. 
The access to increasing sums of money allowed the Company to expand its standing army between Plassey and the Sikh wars (Table 4). The decision to do so was motivated less by long-term planning, and rather more by immediate anxieties regarding the Indian powers. Long before the Company became active in north Indian politics, its obsession with the defences of the Fort William in Calcutta made a Dutch observer remark, 'if they ever lose their power here, their fall will, in all probability, proceed from the heavy expences, which they sustain, in keeping up so important a military establishment... ${ }^{37}$ By contrast, their chief adversaries were in this time becoming dependent on supply of irregular soldiers by their allies. These heavy expenditure commitments exerted a path dependence effect and made military planning a long-term affair rather than one that adapted to every battle.

The increasing financial capacity allowed the Company to make forward-looking employment contracts. A simple comparison of salaries will be misleading, because pay practices depended on the composition of the army. There was, however, an emerging contrast in the implementation of any employment contract. The source of the contrast was the feasibility of altering the proportion of regular and irregular categories. Flexibility in this respect meant that the salaries of the Maratha infantry rarely followed the stated regulations. Haidar Ali paid fixed wages to his cavalry, but stretched by the campaign against the tributary kings, reduced the number of days of service, 'the balance being supposed to be made up by .. plunder'. ${ }^{38}$ The predominance of irregulars and short-term credit made war budget an on-the-spot affair, a good illustration being the financing of Panipat by means of raids in Delhi. There is no record of a pension plan for soldiers in the Indian armies.

\footnotetext{
${ }^{37}$ J.S. Stavorinus, Voyages to the East Indies, London: J. Robinson, 1798, vol. 1 of 3 , p. 498.

${ }^{38}$ Lewin B. Bowring, Rulers of India: Haidar Ali and Tipu Sultan, Oxford: Clarendon Press, 1893, p. 78
} 
Land grants were made, but not according to a stated policy as far as one can see. In the early nineteenth century, the Company had a policy of rewarding long service. The Bengal army resettled invalids and retired soldiers with land grants. ${ }^{39}$ In Madras, half-pay pensions were granted after 22 years of service. ${ }^{40}$ These policies had a practical aim. The challenging task before the Company's military command in the second quarter of the nineteenth century was how to disband large number of soldiers in a peaceful manner. The retirement scheme attained this goal. $^{41}$

At the time of the final conflict with the Marathas, the Company was earning a much larger income than any of the Indian states, from a territorial extent still smaller than that controlled by the Indian states. Only a small part of this income can be explained by tributes from dependent regimes. In 1795, two-third or more of the income was generated internally, whereas only half or less of the cash inflow into the Peshwa's treasury came from land revenue. And this internally generated stream was higher per square mile of territory controlled by the Company, so far as we can measure (Table 2).

The hint that regional resources played a part in the fiscal effort can be confirmed from a more uniform set of data that became available somewhat later in a pamphlet on financial transactions between the Company and the states (Table 5). By the time the data were compiled, c. 1850, the political contest had ended, tribute giving and taking reduced in scale, and in most regions new administrative institutions had been set up. By and large revenues still came mainly from land tax and therefore

\footnotetext{
39 Seema Alavi, 'The Company Army and Rural Society: The Invalid Thanah 17801830', Modern Asian Studies, 27(1), 1993, pp. 147-178.

${ }^{40}$ Lorenzo M. Crowell, 'Military Professionalism in a Colonial Context: The Madras Army, circa 1832', Modern Asian Studies, 24(2), 1990, pp. 249-273.

${ }^{41}$ These achievements were short-term. Accounts of the prehistory of the mutiny suggest an atrophy of the incentive and reward structures and hardening of racial hierarchy in the 1840s.
} 
revenue per square mile should reflect the productive power of the region. A particular virtue of this dataset is that it is from the same source, whereas the data presented in Table 3 is made up of discrete sources. Table 4 suggests that in terms of revenue per capita, Indian regions were quite similarly placed. However, in terms of revenue per unit of land, there was a significant difference. The more advanced regions were, predictably, located in the Gangetic plains. The more poorly endowed regions were situated in the arid peninsular India.

What does the comparison tell us? Overall, the revenue generation potentials of the Gangetic plains were much higher than in the Deccan and central India, because of vast differences in the productivity of land, and the larger extent of forests and wastes, the difficulty of transportation, high trade costs, and poor access to maritime commerce, in the latter. Revenue per square mile can be taken as a proxy for the relative cost of administration. For such costs should bear a positive relationship with the area administered. ${ }^{42}$ On that assumption, any contest between Mysore, Hyderabad, Punjab, Rajputana, or the Maratha spheres in Hindustan, on the one hand, and the Company on the other, was an unsustainable one. This is, of course, not the whole story, for it begs the question of why preBritish Awadh or Bengal had failed to emerge as militarily the dominant force in the eighteenth century.

It is proposed in the next section that the difference reflected the effectiveness with which the Company could subject the intermediate orders to the demands of the treasury. Such strategies stemmed from a manner of political calculation that was not indigenous to India, and had consequences for military policy.

\footnotetext{
42 It is possible to argue that while it could vary positively with population density, relatively wages should fall. A large and sparsely populated territory could raise both types of cost.
} 
Table 4. Approximate Size of Armies, Major Battles and Reserves

\begin{tabular}{|c|c|c|c|c|c|c|c|c|}
\hline & $1740-50$ & $1750-60$ & $1760-70$ & $1770-80$ & $1780-90$ & $\begin{array}{r}1790- \\
1800\end{array}$ & $1800-10$ & 1810-35 \\
\hline Maratha & $80,000^{\mathrm{a}}$ & & $70,000^{b}$ & $56,000^{c}$ & & & $50,000^{\mathrm{d}}$ & \\
\hline Mysore & & & $23,000^{\mathrm{e}}$ & $45,000^{f}$ & $58,000^{f}$ & & & \\
\hline $\begin{array}{l}\text { Pre- } \\
\text { British }\end{array}$ & $25,000^{a}$ & $50,000^{g}$ & & & & & & \\
\hline Bengal & & & & & & & & \\
\hline Awadh & & & & & & $61,200^{\mathrm{h}}$ & & \\
\hline Company & & $3,000^{g}$ & & $35,000^{i}$ & & $70,000^{j}$ & $153,000^{k}$ & $130,000^{\prime}$ \\
\hline
\end{tabular}

a. The size of Maratha army under Bhaskar Pandit sent to Bengal, 1742, and the army of Alivardi Khan. William Bolts, Considerations, pp. 8-9.

b. Panipat, 1761 , including cavalry 56,000 , of which 2,000 belonged to Ibrahim Khan Gardi. Two contemporary accounts on the battle using different sources are, 'An Account of the Battle of Panipat', Asiatic Researches, 3, 1799, pp. 91-140, translation of the Persian manuscript by Casi Raja (Kashiraj) Pandit, vakil of Awadh and an eyewitness; and Seir Mutaqharin of Ghulam Husain Khan, Calcutta: R. Cambray, vol. 3 of 3, pp. 385-9. They produce similar numbers, but also suggest that numbers for Panipat are unreliable, because of the preponderance of irregulars and camp-followers on both sides, numbering several hundred thousands.

c. Wadgaon 1779, cavalry 16,000. M.R. Kantak, The First Anglo-Maratha War, Bombay: Popular Prakashan, 1993, p. 71.

d. Assaye, 1803. The size of the reserve army, like aggregate revenue (see Table 3 ), is estimated to be much larger. But in no single major battle, more than a third of such numbers could be mustered.

e. 1767, Haidar Ali's forces, include 11,000 irregular cavalry. Roy, 'Military Synthesis', p. 668. Also account of the march to Erode, 1768, in Lewin B. Bowring, Rulers of India: Haidar Ali and Tipu Sultan, Oxford: Clarendon Press, 1893, p. 56, and the account of the battle with Eyre Coote in Porto Novo, 1780, Ibid., p. 98, for a similar total but a larger cavalry.

f. 1780 , Haidar Ali's army, 28,000 cavalry. In addition, there were 40,000 'peons' or irregulars. Charles Macfarlane, A History of British India, London: George Routledge, 1853, p. 183. 1790, Tipu Sultan, cavalry 20,000.

g. Battle of Plassey, 1757. 15,000 cavalry in the Bengal side. Peter Harrington, Plassey 1757, London: Osprey, 1994. J.S. Stavorinus reports 50,000 foot and 18,000 horses on the Indian side, and 3,000 on the English side, including 900 Europeans, Voyages to the East Indies, London: J. Robinson, 1798, vol. 1 of 3, p. 486.

h. 1792, potential size comprising of all jagirs, cavalry 13,400. Letters, Political, Military and Commercial on the Present State and Government on the Province of Oudh and its Dependencies, c. 1793.

i. Wadgaon, 1779. Kantak, Anglo-Maratha War, p. 71.

j. 2,340 cavalry.

k. Size of standing army in 1808, 10,400 cavalry. British Parliamentary Papers 1810 (363) Select Committee on Affairs of East India Company Second Report.

I. Size of standing army in $1832,12,000$ cavalry. 
Table 5. Area, Population, and Estimated Revenue, 1853

\begin{tabular}{lrrrrr}
\hline & $\begin{array}{l}\text { Area (sq } \\
\text { miles) }\end{array}$ & $\begin{array}{l}\text { Population } \\
\text { (millions) }\end{array}$ & $\begin{array}{l}\text { Revenue } \\
\text { (million } \text { ) }\end{array}$ & $\begin{array}{l}\text { Revenue/ } \\
\text { capita }\end{array}$ & $\begin{array}{l}\text { Revenue/ } \\
\text { sq mile }\end{array}$ \\
\hline Hyderabad & 80,000 & 10.7 & 1.50 & 0.14 & 18.8 \\
Gwalior & 25,000 & 3.2 & 0.32 & 0.10 & 12.9 \\
Indore & 10,000 & 0.8 & 0.22 & 0.27 & 22.0 \\
Mysore & 29,000 & 4.0 & 0.69 & 0.17 & 23.8 \\
Berar & 113,000 & 4.6 & 0.49 & 0.11 & 4.3 \\
Awadh & 29,000 & 6.5 & 1.40 & 0.22 & 48.3 \\
Mewar & 13,000 & 1.0 & 0.14 & 0.14 & 10.8 \\
Punjab & 105,000 & 14.6 & 1.24 & 0.08 & 11.8 \\
Travancore & 8,100 & 1.3 & 0.46 & 0.36 & 56.5 \\
North-western & 81,500 & 28.2 & 6.12 & 0.22 & 75.1 \\
Provinces & & & & & \\
Bengal Presidency & 155,000 & 42.5 & 11.22 & 0.26 & 72.4 \\
Bombay Presidency & 123,100 & 12.9 & 4.71 & 0.37 & 38.3 \\
Madras Presidency & 139,000 & 22.0 & 5.32 & 0.24 & 38.3 \\
\hline
\end{tabular}

Source: Anonymous, The Native States of India, 1853. The author of the 27-page pamphlet was possibly Edward Thornton, the East India House officer who prepared a number of pre-mutiny Gazetteers, and was also the author of Statistical Papers relating to India, London: East India Company, 1853, which was the main source for the figures. Some of the area figures come from the Statistical Abstracts of India. 


\section{Patterns of Institutional Response}

It is necessary to connect three isolated propositions implicit in the scholarship on the eighteenth century. First, there was a growing distance between regions in the relationship between the state and the intermediate orders, that is, tax officers and land grantees. Second, linked with this divergence, the states had variable capacities to create and control their forces. And third, location mattered to the disciplining capacity of the rulers.

In pre-colonial Bengal, Hyderabad, and Awadh, the structure of proprietary rights followed the Mughal principle of awarding jagirs, and awarding the right to award jagirs, to nobles loyal to the king. These jagirs, however, were treated as heritable property. ${ }^{43}$ In Hyderabad, there was a largely peaceful passage into a harmonious partnership between the ruler and the landholders from the late eighteenth century, made possibly by the retreating military threat. In Awadh, the peaceful transition to a successor state had made the zamindars more powerful and assertive. The Awadh Nawabs were partially successful in containing revolts in the west, whereas in the east, groups with more resources and military strength broke away. Facing the Maratha threat, the regime became militarily dependent on the Company, financially bankrupt, and lost control over the local agents in the fiscal system. English reaction to a crisis that they had themselves created in some measure was at first respectful submission of accounts showing a massive credit balance. The mood changed in the nineteenth century, when intelligence from Lucknow made a thinly veiled case for takeover, since 'without our sepoys [the nawab] could not have .. collected a rupee of revenue. ${ }^{44}$ 'The present sovereign of Oude is just what might be expected of a person brought up

\footnotetext{
${ }^{43}$ Karen Leonard, 'The Hyderabad Political System and its Participants', Journal of Asian Studies, 30(3), 1971, pp. 569-582.

${ }^{44}$ Macfarlane, History, p. 163.
} 
in a harem. ${ }^{45}$ Statements such as these reflected the losing relevance of the Nawab for English interests in north India. But the picture was not far from the truth. What it omitted to mention was that the induced bankruptcy had left few options to the ruler, who concentrated his energies on literary and musical pursuits. Bengal by contrast displayed swings in the balance of power between the state and the substantial landlords who supplied military service as well. Murshid Quli succeeded in wresting more taxes from them. But his harsh punitive measures were never accepted by the nobility, and quickly reversed by his successor. Thereafter, some of the larger estates, such as the Burdwan Raj studied by John McLane, prospered in the eighteenth century. ${ }^{46}$ In the 1740 s, the Nawab Alivardi Khan needed to press many landlords into military service to deal with the Marathas. Faced with potential takeover by the Company, the last independent Nawab Mir Kasim again tried to recast the equation, only to lose in the battlefield.

If in these examples we see the nobility-cum-gentry groups maintain control over arms and the means of collecting money, in the commander-ruled states, we see a propensity towards gifting away these means to commanders. In the case of nearly all the major Rajput states in the eighteenth century, military tenure holders became powerful as a result of the Maratha threat, and often turned kingmakers in their own domain. The most important case, of course, is the Marathas themselves. Although Shivaji had created an apparatus of state, and made some proclamations on good governance, his real legacy was not institutions of state, but an army funded by central resources. The army, consisting of an infantry and a mobile light cavalry, proved itself effective against the Mughal army, the core of which was formed of a cavalry that was heavily

\footnotetext{
${ }^{45} \mathrm{~J}$. Sutherland, Sketches of the Relations subsisting between the British Government in India and the Different States, Calcutta: Military Orphan Press, 1837, p. 45.

${ }^{46}$ Land and Local Kingship in Eighteenth-Century Bengal, Cambridge: Cambridge University Press, 1993.
} 
armed and moved slowly. In the early eighteenth century, there were several such units that joined to lead the main territorial conquests. These bands were individually too small to pose a threat to a large organized army, but sufficiently large and mobile to make imperial armies ineffective. ${ }^{47}$ Outright conquest, in other words, was not always a feasible strategy to raise taxable wealth. But sharp and frequent raids could paralyze the enemy enough to force a negotiation on tax sharing.

With the expansion of the territorial extent under Bajirao I, and the need to maintain military outposts in distant tributary zones, a different form of military-fiscal strategy was required. A general contrast can be drawn between zones of origin and zones of conquest. In zones of origin, that is, in the western Maharashtra territories where the Peshwa ruled, land grants were made to military chiefs to provide sustenance for the troops under their pay, creating a modified jagirdari system. In turn, the jagirdars as well as the state relied on Brahmin and other state officers for conducting the businesses of state. Some of these officers emerged into the mainstream and became landlords in turn. In zones of conquest, on the other hand, the landlords who had served the Mughal provincial state continued to function under the Marathas, who employed a credible threat upon the landlords to make them comply. What kept this machine running was the subsidy from Hindustan contributing to the consolidation of the intermediate order in Maharashtra. The flow was kept in place by a collection of self-financing military outposts at the exterior. The budget of each commander was separated from the central budget, and instead of provinces being financed out of a central pool of resources, the centre was subsidized by tributes from the provinces. As long as tribute came in from zones of conquest to subsidize the zones of origin, the whole could sustain its military enterprise. However, 1761 put a check upon

\footnotetext{
${ }^{47}$ Stewart Gordon, 'The Slow Conquest: Administrative Integration of Malwa into the Maratha domain, 1720-1760', Modern Asian Studies, 11(1), 1977, pp. 1-40.
} 
conquests, and 1803 saw serious territorial loss. The zones of origin, where fiscal administration had deteriorated by then, could not sustain military effort on its own and became a British dependency. The disintegration of the fiscal system had been developing more gradually for a long time. At the time of the alliance with the English, the Peshwa 'has not sufficient power to levy the kist. The jagheerdars of the southern frontier are in a great degree independent of him, and pay him but a trifling, if any tribute. ${ }^{48}$ The dissensions among Maratha chiefs, the increasingly disputatious nature of any accession in Poona, and the withholding of tribute from other branches of the domain even before territorial loss, need to be seen in the context of this endogenous economic crisis.

In Mysore, a great part of the extraordinary energies of Haidar Ali and Tipu Sultan was taken up in centralizing revenue. These efforts were disturbed by the fact that both rulers needed to maintain the flow of money from the tributary kings, which mission dissipated a great deal of the state resources, and made the fiscal enterprise too dependent on territorial expansion. To overcome the dilemma, Tipu issued a set of detailed regulations aiming to nationalize a number of trades, widen tax base, and improve compliance. Historians have come too close to reading Tipu's regulations as evidence of real change. ${ }^{49}$ The effect of the measures, in fact, is a matter of guesswork. The overwhelming focus of the regulations was a direct contract ('a promise of engagement from a superior to an inferior') between the state and the cultivator. The agent in charge of implementing that contract on behalf of the state was the village officer, which was a more or less hereditary office attached to the village and paid for with rent-free land. The regulations make it abundantly clear

\footnotetext{
${ }^{48}$ Anonymous ('An Officer in the Service of the East India Company'), Origin of the Pindaries, London: John Murray, 1818, p. 141.

${ }^{49}$ Nikhiles Guha, Pre-British State System in South India: Mysore 1761-1799, Calcutta: Ratna Prakashan, 1985.
} 
that neither this officer nor the amil (revenue-officer), mutsuddy (clerk) and kelladar (fort in charge) commanded the trust of the state. The regulations are filled with orders that start with the words, 'it has been the practice in the districts', and warning that such practices could invite the 'severest displeasure' of the huzoor (government). These include revenue farming in which clerks, accountants, and other officers indulged in, and the routine practice of village officers coercing the peasants to work their own lands. 'Falsehood is an offence of the highest nature .. and God has declared the lyar to be a companion of Satan' - the regulations remind the amil, who had a realistic hope of evading punishment in this world. ${ }^{50}$ The regulations leave one with the impression that these were attempts to mend a flawed system, flawed in that they were injunctions addressed to an officer-cum-gentry elite who could not be removed from their rights to village assets, and who, using their entrenched power, worked at cross purposes with the state.

The Company's mission in Bengal had been moving on a different trajectory. Soon after British takeover of the fiscal authority of Bengal (1765) and during the first round of land surveys conducted by a Committee of Circuit (1771), the administrators of Bengal agreed that it would be inadvisable to try to raise revenues 'by destroying all the intermediate order of men between the ruler and the cultivator'. ${ }^{51}$ But they also faced a situation where a large number of landlords and their associates failed to meet their revenue engagements from incapacity, mismanagement, or worse, a feeling that the new state like the old ones did not pose a credible threat. This threat earlier materialized in the shape of a visit by a state officer accompanied by a group of armed men, whose

\footnotetext{
${ }^{50}$ British India Analyzed: The Provincial and Revenue Establishments of Tipu Sultan, London: E. Jeffrey, 1793, vol. 1, p. 90.

${ }^{51}$ Philip Francis, Original Minutes of the Governor-General and Council of Fort William on the Settlement and Collection of the Revenues of Bengal, London: J. Debrett, 1782, p. 152.
} 
job it was to inspect the reasons for default, and take punitive action if appropriate. The penalty rarely included dispossession from tenure unless it was a question of disloyalty. This instrument had repeatedly failed to work, even failed to appear, during the Nawabi regime. While expressing the need for a credible threat, the regime upheld the hereditary proprietary rights of the landlords, acknowledging 'that the Zemindars, Talookdars, \&c. were the hereditary proprietors [of land], and gave testimonies in favour of their rights'.

It was considered that ' $[\mathrm{t}] \mathrm{h}$ e fear of the sale of their lands is the only probable instrument of keeping them to their engagements; and the actual sale of them is the only means of reimbursing the Government if they fail, ${ }^{52}$ A universal rule by coercion would be inviting trouble. A rule by market had the advantage that it separated the good from the bad zamindar, and reduced the costs of policing. The only resistance to the scheme was likely to come from the larger zamindars. The policing problem was to ensure compliance of these people. Subdivision of estates into smaller lots, whether via auction or inheritance law was in this context 'for the interest of the Government'. ${ }^{53}$

How was this mechanism put in place? Between 1770 and 1793, landlord asset was made more marketable, and increased in value as collateral. The Company was beginning to overhaul the legal infrastructure by instituting a set of courts and uniform procedural law. The claim to landed property became verifiable in the courts of common law rather than the courts of Islamic law, courts of the royalty, or courts of the peasant communities as before. Further, the state made the statelandlord relationship a contractual one, meaning that the failure to pay revenues led to resumption and sale of estate to the highest bidder. The revenue auction element diluted and weakened the military element

\footnotetext{
52 Ibid., p. 12.

53 Ibid., p. 16
} 
among the landlords, as it did in Awadh and Hyderabad, and brought in bankers and officers of state into the landlord cadre. On the other hand, the presence of common law courts defined and strengthened landlord right. It was this quid-pro-quo that explains why the revolution could be carried through with comparatively little resistance from the landlords. These two principles were generalized in the Permanent Settlement of 1793. What followed these reforms is too well-known to be repeated in detail. An outburst of auction sales did splinter the large estates, and brought in a whole set of new people. ${ }^{54}$ Within a few years, the military and nobility element in the landlord class had completely dissipated. The outcome of the new paradigm on revenues was dramatic. Bengal revenues increased from a figure nearer $£ 2$ million in the last days of the Nawab to over $£ 5$ million 25 years after Company takeover. The increase was achieved not by making land produce more, but wholly by wresting more from the landlords.

The relationship between the state and the intermediate order cast a shadow on the formation of the army. The Indian armies were constituted of soldiers supplied by the holders of military-fiscal tenures, with a large number of irregulars among them. Such decentralization saved the king much money, but made three types of hazard more likely. First, the commanders tended to include spoils from predatory raids into their reward structure, which made the level of war effort conditional upon prospect of personal gain. Second, the coalitional nature of the large armies made command a difficult problem. The decentralized nature of the army could cause adverse chain reaction. When the chance of a defeat increased during a battle, factions left the battlefield increasing the likelihood of defeat. On one occasion when the divided command was to cause utter devastation, Panipat, the commanders had taken 'no account

${ }^{54}$ B.B. Chaudhuri, 'Agrarian Relations: Eastern India', in Dharma Kumar, ed., The Cambridge Economic History of India, vol. 2, 1983, p. 94. 
of any troops but those immediately under their own. ${ }^{, 55}$ More generally, Maratha 'Sirdars followed their own interests', a Maharashtrian historian observed. ${ }^{56}$ Clearly, they needed to since they paid for their own troops. It was only on rare occasions that charismatic chiefs held disparate factions together. And their death led the whole army to slide back into chaos. This is what happened to the Sindhia army after the death of Mahadaji, and the Sikh army after Ranjit Singh. In both cases British victory in battlefield owed to factionalism. The Indian states' attempts to induct Europeans created new conflicts of interest. The mixing of command structures and patterns with the induction of the Europeans left units confused and indecisive. The exit of Benoit de Boigne in 1795 weakened and divided military command in the Sindhia camp. The new General Pierre Cuillier-Perron was not trusted by the king, Daulatrao, and as it turned out a few years later, nor by many of the officers, Indian and European.

The third problem was posed by the irregulars. For an idea of the scale, at Panipat, irregulars outnumbered regular soldiers 4:1 in the Durrany camp, and irregulars and camp-followers outnumbered soldiers 8:1 in the Maratha camp. The loss of life on a genocidal scale at this battle had much to do with the preponderance of non-combatants and semi-combatants. The number of camp-followers was large in the Company's army as well, but maintained a considerably smaller ratio, 3:1 according to a 1791 statement. ${ }^{57}$ Being responsible for their capital cost, irregular soldiers were risk-averse and could not be easily integrated into military strategy. Towards the end of the century, the most important group among Maratha irregulars were the pendhary or Pindari, light cavalry who owned their horses and equipment, were not compensated if injured or suffered loss of horse, and therefore, felt no particular

\footnotetext{
${ }^{55}$ Seir Mutaqharin of Ghulam Husain Khan, Calcutta: R. Cambray, vol. 3 of 3, p. 387.

${ }^{56}$ Nadkarni, Rise and Fall, p. 355.

${ }^{57}$ Ibid., p. 136.
} 
allegiance to any leader other than their own headmen. In peacetimes they pursued agriculture or other professions, during battles they were called in or joined on their own. There was a close association between conditions of agriculture and the incentive to join the irregular forces. '[T]he numbers of the Pindaries may be said to increase in the same ratio, as the means of subsistence diminish. ${ }^{, 58}$ For the main force, they had value in raiding campaigns. 'In action, it was their custom immediately after the regulars had charged and broken the enemy, to fall upon them sword in hand, and complete the rout. ${ }^{59}$ But they could become a liability in a battle against a disciplined army.

The Pindaries were not popular with any of the major powers of the time. And yet, the logic of conflicts in the eighteenth century increased the supply of such soldiers to any new state that might wish to make use of them. Every military debacle released a large number of stragglers, deserters, and soldiers without command. Mercenary units that enlisted such people performed a significant column of support for the new armies raised. ${ }^{60}$ Mahadaji Sindhia recruited from the remnants of Panipat, Ranjit Singh from the remnants of Assaye and Laswari, and the Holkars from the disbanded soldiery of Awadh and Rohilkhand. Some of them were retrained and absorbed in the regular army, but many remained outside the core army. Tipu Sultan's cavalry consisted of three units, the regulars (silahdars), the regulars who supplied their own horses, and kazzaks or predatory cavalry irregulars. The last formed the largest body. ${ }^{61}$ As military conflicts intensified, and states found their territorial control shrink, the dependence on irregulars became greater. At the end of the final Anglo-Maratha wars, the northern armies relied mainly on the pindaries.

\footnotetext{
${ }^{58}$ Anon., Origin of the Pindaries, p. 127.

59 'An Account of the Battle of Paniput', p. 105.

${ }^{60}$ For a study of the Indian military labour market in early eighteenth century Bengal, Ratan Dasgupta, 'Mercenaries and the Political Economy of Bengal: 1727-63', Social Scientist, 13(4), 1985, pp. 17-30.

${ }^{61}$ Bowring, Rulers, p. 213.
} 
Whereas the Indian military enterprise was increasingly dependent upon what one historian calls 'old feudal elements', the Company could create a unidirectional command structure owing to its reliance on regular forces. ${ }^{62}$ More than the reliance on regular soldiers, the recruitment structure made a difference. The Company recruited its main body of soldiery from the Gangetic plains. At the time of the Anglo-Maratha wars, the Company did also recruit Rohilla and European mercenaries, but recruiting from other armies was not the preferred strategy. Brahmin and Rajput peasants recruited in Awadh and Benares formed the core of the standing army in Bengal. In Bombay a deliberate attempt was made to recruit down the caste hierarchy, and in Madras, no single community was allowed to dominate. In the major example of northern India, many of the recruits probably overlapped with the category of armed peasantry whose history Dirk Kolff has explored. ${ }^{63}$ But even if they did, the majority did not enjoy an entrenched position in a state army before joining Company's service. Even the so-called upper caste Bhumihar Brahmins in Benares came from a milieu were their superior status had been disputed. Through carefully crafted social policies that maintained a caste hierarchy inside the barracks, the Bengal army managed to preserve a situation in which the soldiers felt they enjoyed a higher status in the army than outside. ${ }^{64}$

\footnotetext{
${ }^{62}$ Pradeep Barua, 'Military developments in India, 1750-1850', Journal of Military History, 58(4), 1994, pp. 599-616. See also for a similar view, Stewart Gordon, 'The Limited Adoption of European-style Military Forces by Eighteenth Century Rulers in India, Indian Economic and Social History Review, 35(3), 1998, pp. 229-245.

${ }^{63}$ Naukar, Rajput and Sepoy. The Ethnohistory of the Labour Market in Hindustan, Cambridge: Cambridge University Press, 1990.

${ }^{64}$ This part of the military strategy had been disputed by insiders for what they saw was a dangerous compromise of military order. After the Anglo-Burma wars of 1824-6 and a mutiny among Indian soldiers in Barrackpore in 1824, a disillusionment with the social policy set in; and reforms in the barracks gave up the privileging of Indian tradition in favour of hierarchy based on a mixture between military order and racialist ideas. There were other factors that undermined the finely balanced caste system inside the barracks. The upper caste soldiery lost some of their status due to a fall in real wages, whereas in the Burma campaigns, low-caste recruits were paid higher wages. Douglas
} 
The Company could pursue this course thanks to its location near the coasts and the delta. Location translated into military advantage in a number of ways. The principal one, of course, was revenue per area. The Company also had access to a large body of urban skilled labour based in Bombay. ${ }^{65}$ At the time of the second Anglo-Maratha wars, at short notice, labour contractors and headmen could gather carpenters, loggers, and blacksmiths together, to build carriages for artillery. Parsi merchants took supply contracts for food. In turn, Bombay's situation as a port made it possible for the merchants to import Bengal rice for the troops. Disputes over contracts between merchant-suppliers and the stores in-charge did occur, but the form of a legal contract made such disputes in principle negotiable by a third party. Most importantly, the Bengal army had a virtual monopoly of saltpeter supplies and all three ports could cast cannons and iron implements on a larger scale and in better quality than did enemy forces. In short, access to the port cities with a pool of industrial skills and commercial capital offset the disadvantage that distance from the overland supply routes could cause.

These overland supply chains were in decay. The early eighteenth century Maratha cavalry was legendary for its ability to subsist on little food. A few handfuls of millets collected from cropped field en-route and consumed on horseback were all that the riders lived on for days. Even if these reports were exaggerated, the small size of these bands made supplies a less serious problem than was the case with the Mughal armies. However, as the battles became bigger and the forces larger supplies were organized differently. The overland supply system relied on Banjara bullock trains. The Banjara chieftains, according to later English

M. Peers, "The Habitual Nobility of Being": British Officers and the Social Construction of the Bengal Army in the Early Nineteenth Century', Modern Asian Studies, 25(3), 1991, pp. 545-569.

${ }^{65}$ Randolf G.S. Cooper, 'Beyond Beasts and Bullion: Economic Considerations in Bombay's Military Logistics, 1803', Modern Asian Studies, 33(1), 1999, pp. 159-183. 
documents, had a special relationship of regard with the Marathas. The system was slow, and with territorial losses, at increasing risk of interception. On several occasions, beginning with Panipat, the Maratha troops were starving when real battle commenced.

\section{Conclusion}

To sum up, numbers suggest that the Company alone managed to achieve mutually reinforcing growth in wealth and power in eighteenth century India. An enabling factor working in their favour was a base in resource-rich Bengal and a tributary-cum-predatory relationship with the second richest land, Awadh. While playing the competitive game of judicious predation, which all prominent military powers in this time played, the Company also changed the rules of the game. It changed the equation between the state and the groups in command of local power. It relied on their loyalty to a lesser extent than did the others, and subdued them by a new instrument, the land market. At the same time, persistence with shared sovereignty weakened the Indian states in the face of sustained conflict.

I conclude by returning to a global history question that this paper started with. Why did political competition empower states in early modern Europe, and disempower states in early modern India? Perhaps we need to understand the goals of competition and the means of competition differently in the Indian example. Initially, the goal was judicious predation, and the means militarism rather than governance. These means were unsustainable when conflicts became long-term. The Company succeeded in adapting the means by wresting control of the fiscal order from former commanders and nobles, even as its Indian rivals persisted with the tradition of rewarding commanders and nobles with 
fiscal powers. As the divergence in means continued to grow, the goal before the Company changed from predation to imperialism. 


\section{LONDON SCHOOL OF ECONOMICS}

\section{ECONOMIC HISTORY DEPARTMENT WORKING PAPERS}

(from 2006 onwards) For a full list of titles visit our webpage at

http://www.Ise.ac.uk/

2007

WP97 An Historical Analysis of the Expansion of Compulsory Schooling in Europe after the Second World War Martina Viarengo

WP98 Universal Banking Failure? An Analysis of the Contrasting Responses of the Amsterdamsche Bank and the Rotterdamsche Bankvereeniging to the Dutch Financial Crisis of the 1920 s Christopher Louis Colvin

WP99 The Triumph and Denouement of the British Fiscal State:

Taxation for the Wars against Revolutionary and Napoleonic France, 1793-1815. Patrick Karl O'Brien

WP100 Origins of Catch-up Failure: Comparative Productivity Growth in the Hapsburg Empire, 1870-1910

Max-Stephan Schulze

WP101 Was Dick Whittington Taller Than Those He Left Behind? Anthropometric Measures, Migration and the Quality of life in Early Nineteenth Century London Jane Humphries and Tim Leunig

WP102 The Evolution of Entertainment Consumption and the Emergence of Cinema, 1890-1940 Gerben Bakker

WP103 Is Social Capital Persistent? Comparative Measurement in the Nineteenth and Twentieth Centuries Marta Felis Rota

WP104 Structural Change and the Growth Contribution of Services: How Motion Pictures Industrialized US Spectator Entertainment Gerben Bakker 
WP105 The Jesuits as Knowledge Brokers Between Europe and China (1582-1773): Shaping European Views of the Middle Kingdom Ashley E. Millar

WP106 Regional Income Dispersion and Market Potential in the Late Nineteenth Century Habsburg Empire Max-Stephan Schulze

\section{8}

WP107 'The Big Problem of the Petty Coins', and how it could be solved in the late Middle Ages Oliver Volckart

WP108 The Anglo-German Industrial Productivity Puzzle, 1895-1935: A Restatement and a Possible Resolution Albrecht Ritschl

WP109 The History, Nature and Economic Significance of an Exceptional Fiscal State for the Growth of the British Economy, 1453-1815 Patrick O’Brien

WP110 The Economic History of Sovereignty: Communal Responsibility, the Extended Family, and the Firm Lars Boerner and Albrecht Ritschl

WP111 A Stakeholder Empire: The Political Economy of Spanish Imperial Rule in America Regina Grafe and Alejandra Irigoin

WP112 The U.S. Business Cycle, 1867-1995: Dynamic Factor Analysis vs. Reconstructed National Accounts Albrecht Ritschl, Samad Sarferaz and Martin Uebele

WP113 Understanding West German Economic Growth in the 1950s Barry Eichengreen and Albrecht Ritschl 
WP114 War and Wealth: Economic Opportunity Before and After the Civil War, 1850-1870

Taylor Jaworski

WP115 Business Cycles and Economic Policy, 1914-1945: A Survey Albrecht Ritschl and Tobias Straumann

WP116 The Impact of School Provision on Pupil Attendance: Evidence From the Early $20^{\text {th }}$ Century

Mary MacKinnon and Chris Minns

WP117 Why Easter Island Collapsed: An Answer for an Enduring Question

Barzin Pakandam

WP118 Rules and Reality: Quantifying the Practice of Apprenticeship in Early Modern Europe Chris Minns and Patrick Wallis

WP119 Time and Productivity Growth in Services: How Motion Pictures Industrialized Entertainment Gerben Bakker

WP120 The Pattern of Trade in Seventeenth-Century Mughal India: Towards An Economic Explanation Jagjeet Lally

WP121 Bairoch Revisited. Tariff Structure and Growth in the Late $19^{\text {th }}$ Century

Antonio Tena-Junguito

WP122 Evolution of Living Standards and Human Capital in China in 18-20 $0^{\text {th }}$ Centuries: Evidences from Real Wage and Anthropometrics Joerg Baten, Debin Ma, Stephen Morgan and Qing Wang

WP123 Wages, Prices, and Living Standards in China, 1738-1925: in Comparison with Europe, Japan, and India Robert C. Allen, Jean-Pascal Bassino, Debin Ma, Christine Moll-Murata, Jan Luiten van Zanden 
WP124 Law and Economic Change in Traditional China: A Comparative Perspective

Debin Ma

WP125 Leaving Home and Entering Service: The Age of Apprenticeship in Early Modern London Patrick Wallis, Cliff Webb and Chris Minns

WP126 After the Great Debasement, 1544-51: Did Gresham's Law Apply?

Ling-Fan Li

WP127 Did Globalization Aid Industrial Development in Colonial India? A Study of Knowledge Transfer in the Iron Industry Tirthankar Roy

WP128 The Education and Training of Gentry Sons in Early-Modern England

Patrick Wallis and Cliff Webb

WP129 Does Trade Explain Europe's Rise? Geography, Market Size and Economic Development Roman Studer

WP130 Depression Econometrics: A FAVAR Model of Monetary Policy During the Great Depression Pooyan Amir Ahmadi and Albrecht Ritschl

WP131 The Economic Legacies of the 'Thin White Line': Indirect Rule and the Comparative Development of Sub-Saharan Africa Peter Richens

WP132 Money, States and Empire: Financial Integration Cycles and Institutional Change in Central Europe, 1400-1520 David Chilosi and Oliver Volckart

WP133 Regional Market Integration in Italy During the Unification (1832-1882) Anna Missiaia 
WP134 Total Factor Productivity for the Royal Navy from Victory at Texal (1653) to Triumph at Trafalgar (1805)

Patrick Karl O'Brien FBA and Xavier Duran

WP135 From Sickness to Death: The Financial Viability of the English Friendly Societies and Coming of the Old Age Pensions Act, 1875-1908 Nicholas Broten

WP136 Pirates, Polities and Companies: Global Politics on the Konkan Littoral, c. $1690-1756$

Derek L. Elliott

WP137 Were British Railway Companies Well-Managed in the Early Twentieth Century? Nicholas Crafts, Timothy Leunig and Abay Mulatu

WP138 Merchant Networks, the Baltic and the Expansion of European Long-Distance Trade: Re-evaluating the Role of Voluntary Organisations Esther Sahle

WP139 The Amazing Synchronicity of the Global Development (the 1300s-1450s). An Institutional Approach to the Globalization of the Late Middle Ages

Lucy Badalian and Victor Krivorotov

WP140 Good or Bad Money? Debasement, Society and the State in the Late Middle Ages

David Chilosi and Oliver Volckart

WP141 Becoming a London Goldsmith in the Seventeenth Century: Social Capital and Mobility of Apprentices and Masters of the Guild

Raphaelle Schwarzberg

WP142 Rethinking the Origins of British India: State Formation and Military-Fiscal Undertakings in an Eighteenth Century World Region

Tirthankar Roy 